\title{
From the Desk of Editor-in-Chief
}

\section{Ramesh Chandra Sinha ${ }^{1}$}

Published online: 2 June 2020

(c) ICPR 2020

This issue of JICPR attempts to shape our philosophical views of post covid-19 scenario of the world. The startling change due to corona virus led editor-in-chief to ask scholars of Philosophy to write about powerful new concept of philosophizing. A new phrase known as 'new normal' has come in vogue. This 'new normal' is a concept which has two components. One is survival; the other is distancing. In the era of post covid-19, the human survival is great one. If man survives, he can do philosophizing. If man survives then only other ideas will come to mind. The new phenomenon of 'new normal' is bothering the philosophical community. It is true that we will be free from this alarming corona virus but life will not come to normalcy. Philosophical concern is also relating to this worldly affair. The metaphysical and epistemological questions are put to margin. This new normal will impel man to cover the face with mask and practice distancing. This issue is being published when readers are overwhelmed by pandemic and its consequences. The philosopher has to learn the way in which we adapt or fail to adapt to the post covid-19 scenario. The philosophy journals are required to be concerned with human existence instead of logical chopping of concepts. After the lifting of lockdown necessary steps are likely to be taken to shape our philosophical vision. Philosophers have to deal everyday matters. The term 'covid-19' has shattered our life. It prompted disorientation that we induce in individuals by subjecting them to much change in too short a time. Covid-19 is real sickness from which large numbers of people are already suffering. It is disease of change. The purpose of this issue of JICPR is to help students and teachers to come to terms with the future. We have to cope more effectively with both personal and social change by deepening our philosophical understanding of life and world.

There are well articulated philosophical articles in this issue. Devi B. DillardWright, the author of the article 'A Note on Rta and Dharma: Restoring the Cosmological Principle' stipulates that the Vedic notion of Rta is more comprehensive than the notion of Dharma and Karma. Rta is woven throughout the Rig Vedic hymns. Rta is cosmic principle. Rta encompasses cosmic, moral and social order. Md. Abdul Mannan in his research article titled 'Revolution Versus Evolution: The Pattern of

Ramesh Chandra Sinha rcsinha22@gmail.com

1 Indian Council of Philosophical Research, New Delhi, India 
Conceptual Change in Science' envisages the pattern of conceptual change in science. He shows that process of evolution rather than revolution presents the real situation of scientific change. 'The Essence of Myth' by Jon Mills has explored the significance of structure and essence of the myth. He has offered a theoretic typology of myth by engaging the work of Robert A. Segal. He argued that both interpretation and explanation are acts of explication. He adheres that essence of myth is a form of inner sense. In the article 'Impression of Celestial Being (Deva) on Human Beings in Jainism', written by Samani Amal Pragya and Sonam Jain have attempted to work out the spiritual philosophy of Jainism. They focused on the ultimate purification of the soul. Man can be guided by the 'Deva' and can establish a new system in a society. In Jain literature 'Deva' celestial being will help man to move in the right direction. Vivek Kumar Radhakrishnan upholds that Kant's theory of moral action faces a serious difficulty concerning motivation in his article 'Kantian Moral Motivation: An Affectivist Interpretation'. The question is: How do commands a pure practical reason move human agents to perform moral actions? Kant claims that human agents perform moral actions out of respect for the moral law. This paper develops positive role of respect as a motive. The article 'Foucault-Derrida Debate on Cartesian Cogito: One Step Forward and Two Steps Backward' by Prof. Raghwendra Pratap Singh has reflected about the philosophical debate on Rene Descartes' doctrine of cogito. Pramod Kumar Singh elaborated the Śankara's notion of Ātman and Husserl's transcendental ego in his article named 'Some Observations on Shankara, Husserl and the Transcendental Ego'. In this article he tries to establish the similarity between Ātman and transcendental ego. The article 'Synthesis and Transcendental Ego: A Comparison of Kant and Husserl' written by Saurabh Todariya, argued about the difference between Kant and Husserl's notion of transcendental ego. In this paper he tries to understand and compare the methodological and philosophical difference between the concept of Kant and Husserl on transcendental ego. Christopher Joseph Xavier articulated the views and notion of Darśana in his paper entitled 'Some Contemporary Views on the Nature of Darśana'. He raises the question: Whether to restrict the 'Darśana' to orthodox schools? This paper focuses on the notion of Darśana from the views of some of the prominent Indian philosophers.

I wish to express my thanks to all the authors and the editorial board. It is my pleasure to release the May 2020 issue to researchers, teachers and academic community.

\section{Ramesh Chandra Sinha}

Editor-in-Chief.

Publisher's Note Springer Nature remains neutral with regard to jurisdictional claims in published maps and institutional affiliations. 